\title{
Exploring Transformative Journeys through a Higher Education Programme in a Further Education College
}

Abstract

This article describes a research project designed to understand the experiences of students undertaking higher education in a further education setting in the UK. Since the 1960s, there has been a sustained policy commitment in the UK to widen participation in education to social groups previously under-represented (Thompson, 2000; Burke, 2012), leading in part to the current government mantra that one should be either earning or learning (Burke, 2012). The consequence is a discourse in which it is argued that higher education has been dumbed down to include 'non-traditional students' frequently ill-prepared for academic challenges (Haggis, 2006). This research explored an alternative discourse, proposing that education should be a catalyst for significant social, emotional, and intellectual growth, culminating in a transformative experience (Mezirow, 1978a, 1991; Cranton, 2006).

Twelve non-traditional graduates from a full-time BA programme at a Scottish College of Further and Higher Education were interviewed to determine if graduates experienced significant social, emotional, and intellectual growth as a result of participation; what teaching and learning settings make this possible; can it be proposed that graduates can be transformed by the experience of higher education in further education (hereafter HE in FE)? The findings of the research indicate that the participants all experienced some significant shift in attributes such as confidence, independence and willingness to try new things. How they experience, conceptualise and participate in their social worlds has become more discriminating. We conclude by 
proposing that HE in FE can have the potential to provide transformative experiences for non-traditional students. The implications of this study lie as much in the nature of the transformative learning experience as in the structures in which education is provided. Additionally, it is proposed that transformative teaching and learning theory may be as significant now as it ever was in understanding the changes which learners experience in higher education study.

Key words: transformative learning; widening participation; non-traditional students; higher education in further education colleges. 


\section{Introduction}

Transformative learning theory has an enduring quality. Notwithstanding short hiatuses during which time interest in the theory enters a period of quietude, a new publication or conference can re-ignite scholarly interest (cf. Cranton, 2006; Taylor and Cranton, 2012). Nonetheless, transformative learning theory has received some relatively intense criticism (Taylor and Cranton et al, 2012; Newman, 2012; Hoggan, 2015). The purpose of this article is threefold. First, to briefly review the literature to report the basis on which transformative learning theory has been criticised. Second, to offer a rejoinder to the criticism; arguing that if teachers encourage students to "critically reflect and challenge" their perspectives and assumptions, something like transformation is likely to occur (Bitterman, 2015). Third, to explore approaches to teaching and learning, from where it might be anticipated, that instances of transformation could emerge.

The utility of transformative learning theory will be interrogated in the context of a doctoral study undertaken by one of the authors. The study was situated in a Scottish College of Further and Higher Education. Data was yielded from in-depth interviews with graduates of a social science-based BA degree. Data was used to construct short, but hopefully insightful, transformation stories, emphasising why teachers, aspiring to generate meaningful and lasting change in learners, find transformative learning theory a useful organising concept. An appropriate place to begin might be the early work of Jack Mezirow (1975; 1978a, 1978b, 1981); initially to map the emergence of transformative learning theory, and then to define what we mean by our proposition that participation in learning can be transformative. 


\section{Defining transformative teaching and learning}

Mezirow concluded, from studies of the factors that influenced women's experiences of programmes at community colleges in the USA, that participation in learning encourages a significant challenge to existing, usually deeply entrenched, frames of reference (worldviews). When challenged, they can be found faulty or inadequate, then modified or replaced by more authentic or trustworthy frames of reference (Mezirow, 2000). A number of studies have demonstrated the efficacy of transformative learning theory, as an organising concept, in a range of contexts; for example informal adult education (Dirkx, 1998), higher education (King, 1997), family therapy (Egan, 1985), healthcare (Philipi, 2010), and the workplace (Watkins and Marsick et al, 2012). As stated earlier, our focus will be higher education programmes delivered in further education colleges.

One of the tenets of higher education study impressed upon students is the need to engage in critical dialogue with self, peers and teachers. It is from rich and meaningful critical dialogue that transformation can take place (Mezirow, 2000; see also Habermas, 1984). Teaching approaches that support critical dialogue will be discussed later. However, at this point we acknowledge first that we view transformation as an outcome of students participating meaningfully in learning; but also that transformation is often fiercely contested and subjected to shifting definitions (Cranton, 2006). For example, a simple definition of transformative learning could be, "all learning that implies change in the learner" (Illeris, 2014, p. 40). A more elaborate definition, from the Transformative Learning Centre at the Ontario Institute for Studies in Education, better reflects the aspiration we have for students, 
Transformative learning involves experiencing a deep structural shift in the basic premises of thought, feelings, and actions. It is a shift of consciousness that dramatically and permanently alters our way of being in the world. Such a shift involves our understanding of ourselves and our self-locations; our relationships with other humans and with the natural world; our understanding of relations of power in interlocking structures of class, race and gender; our body awareness; our vision of alternative approaches to living; and our sense of possibilities for social justice and peace and personal joy (Cranton, 2006, p. 48).

Such a description is a helpful one, if dramatic: touching on the shift of consciousness, a paradigm shift rather than just a slight change; and a broad and complex set of changes rather than one alteration.

\section{Critiques of transformative learning theory}

Transformative learning theory has not been without its critics. For example, transformation is little more than a metaphor argues Newman (2012). Consequently, Newman continues, far too much is made of the established rhetoric of transformation and the eureka experiences of research respondents. The rhetoric may deny the ordinary and everyday experiences from which transformation may equally emerge (Dirkx, 2000). The key theme of transformative learning theory is the aspiration to initiate social, emotional, and intellectual change. Newman (2012) rightly reminds us however that all learning involves change, and merely getting students into a classroom after a lengthy hiatus, signifies that change may have already occurred. Nonetheless, transformative learning theory is now bolted on to almost any kind of learning outcome, seldom serving as a "coherent theory" (Hoggan, 2015, p. 58). We therefore concur with Cranton who proposes that merely engaging in a college education is not transformative. Neither is learning new skills or meeting new people with different 
points of view. Nor does achieving a degree necessarily constitute a transformative experience (Cranton, 1996).

Also, the nature of any social phenomenon ought to be understood, and described, prior to theories being posited about the distribution of the phenomenon or of causal relationships (Merriam and Kim, 2012). As there is currently little critical research to validate theories of transformation, the theories that do exist may be conceptually uncertain (Illeris, 2014), and may have little direct implication for teaching and learning (Taylor, 2000). Snyder (2008) highlights research design issues when investigating transformative learning. To say that something has been transformative is both subjective and something of a self-fulfilling prophecy. To make claims that any learning has been transformative requires the use of longitudinal studies or at least the use of follow-up mechanisms to offer some confirmation that transformation has been sustained. Transformation can be an exciting concept that research respondents might want to be seen to have experienced. More rigorous methods of triangulation would control against issues of respondents' "faking it" (Snyder, 2008, p. 176).

\section{A rejoinder}

While we concede that Newman (2012), Illeris (2014) and Cranton (1996) make important points, we argue also that, to a significant degree, they undervalue the empirical and conceptual efficacy of transformative learning theory. For example, although an imprecise concept, and difficult to operationalise, King (2004) attaches meaning to transformation by reporting instances of change that includes for example a) being significantly more open-minded, b) allowing for multiple perspectives of social phenomena, and c) reconsidering the way the world appears to (now transformed) 
research participants. Thirty-six of fifty-eight participants in her study of students' transformative experiences reported these changes, which are unlikely to be inconsequential. They may be "deeply felt", may indicate significant shifts in the way these participants read the text of their own experiences, and consequently should be considered evidence of some transformation at least (King, 2004, p. 162).

Nonetheless, most published work on transformation is, as Newman (2012) suggests, theoretical in nature. Most empirical work has been undertaken by doctoral students and remains unpublished (Walton, 2014). Researchers are now however, finding effective research designs to evaluate and report processes of transformation by applying multiple data pathways (Snyder, 2008). As this research finds its way into the academic literature, a more rigorous empirical and theoretical base for transformative teaching and learning may emerge. More precise measures of transformation are urgently needed if transformative learning theory is to avoid being critiqued for its lack of scientific rigour; in particular, its inability to satisfy the criteria of internal validity, in terms of what is being measured; and external validity, in terms of the practical utility of such an inexact concept. Nonetheless, typical of much research on learning outcomes for adults where there are no qualifications, we are dependent on what students say they have learned (Learning and Work Institute, 2017; Lavender et al, 2004). Trusting those who have been involved in the process seems a reasonable start. Also, being able to identify instances of transformation is important as it is a concept that can be applied to myriad contexts (cf. Dirkx, 1998: King, 1997; Egan, 1985; Philipi, 2010; Watkins and Marsick et al, 2012). 
Returning to education, the power and cogency of transformative learning theory emerges from the quality and depth of the learning experience, evidenced by the selfassessment of change that manifests as a consequence (see King, 2004).

Transformative teaching and learning is therefore less about how much is learned or understood. It is more about "how learning changes the learner" (Cross, 1999, p. x). We intend to return to defining what exactly it is that is to be transformed later. At this point however, some important points need to be made about the constituency of students involved in $\mathrm{HE}$ in $\mathrm{FE}$; the understanding of which might be an indicator of the potential for transformation to take place. The next few paragraphs will describe the type of students who, for reasons of convenience, confidence or education-readiness, find their way into HE in FE.

\section{Who is to be transformed?}

When contrasted with undergraduate students in Higher Education Institutions (HEIs), HE in FE disproportionately attracts non-traditional students (Burke, 2012). By nontraditional students we mean those who have some common characteristics. Nontraditional students tend to be over the average age of traditional students; commonly returning to education following a lengthy hiatus away from formal learning. They tend to gravitate towards colleges rather than universities, often as a consequence of "weak learner identities" (Lawson, 2014, p. 344). Alternatively, traditional students typically enrol in university undergraduate programmes following a seamless transition from compulsory education. They will have attained what are considered Gold Standard qualifications with real academic currency; usually Highers in Scotland or Advanced 
Levels in England (Hawkins and Mill, 2010). They consequently have "strong learner identities" (Lawson, 2014, p. 344). Non-traditional students also tend to have competing responsibilities such as jobs, children, and caring roles. Traditional students would not typically have these responsibilities. For non-traditional students, juggling these responsibilities can have an impact on the learning experience ( $c f$. Pascall and Cox, 1992; Cappleman-Morgan, 2005; Creasy, 2013). Further, it is often assumed that non-traditional students lack the skills, education and advantages associated with traditional students (Leach, 2011, p. 248), and are "under-prepared for academic rigour" (Hawkins and Mills, 2010, p. 11; Burton and Golding Lloyd et al, 2011; Arum and Roska, 2011).

As HE tutors we strive to nurture a learning milieu that promotes and increases possibilities of transformation. Nonetheless, we recognise that, as suggested above, not every HE in FE student is ready for transformation (Bitterman, 2015); rarely are they ready to "develop and realise their potential" (McArthur, 2011, p. 742; cf. Parker, 2003; Brookfield, 2015). Often caught in what one critic referred to as a "short-sighted search" for a passport to the world of work, for many students, participation in education is purely instrumental (Daloz, 1990, p. 75). It is certainly true that employers increasingly demand qualifications and many students may now participate reluctantly as an economic necessity (Hultberg and Plos et al, 2008). Consequently, for education to be transformative there ought to be a deeper intellectual curiosity than is characteristic of most HE in FE students (Cooper, 2013; Arum and Roksa, 2011). 


\section{Transforming the self-identity}

It has been suggested that in Mezirow's early observations of transformation, his emphasis on transforming meaning perspectives, frames of reference and habits of mind might have been limiting and "too much related to cognitive learning" (Illeris, 2014 , p. 32). Illeris suggests that while these concepts offer a good point of departure for transformative learning theory, the change that is sought in the individual should be much deeper. Meaning perspectives, frames of reference and habits of mind simply do not fully "capture the whole range of what transformative learning can address" (Illeris, 2014 , p. 39). Illeris posits his own definition of transformative learning, arguing that transformative learning comprises all learning that implies change in the identity of the learner (Illeris, 2014, p. 40). We can deduct from this definition that transformation should represent not only a total change in life perspective [worldview], but also an actualisation of that perspective. In other words, life is not seen from that perspective, it is lived from that perspective, indicating a meaningful shift in the learner's identity (Mezirow, 2000; Illeris, 2014).

Abraham Maslow called this shift self-actualisation. "The desire for self-fulfilment", for Maslow, represents the aspiration "to become everything that one is capable of becoming" (Maslow, 1943, p. 382). Carl Rogers (2004) referred to the self-actualised individual as a "fully functioning person" (p. 184). For Illeris (2014) someone who is functioning fully has become both the person she "wants to be ... who others experience [her] to be" (p. 47). Transformation should "alter our very being, our beliefs, and our core sense of self"; it should determine the future of "how we live" (Tisdell, 2012, p. 22). We might take issue with Illeris' argument about identity of course, on the grounds that each of us may have a number of identities as Sen (2006) 
suggests, but the point still stands; transformation is major and life changing. How teaching and learning is facilitated, and how teacher-student relationships are nurtured, are important determinants of transformation (Rogers, 1983; Daloz, 1986, 1999; Arum and Roksa, 2011). It is to teaching and learning, with a focus on the context of the BA programme, we now turn.

\section{What kinds of teaching and learning approaches can transform?}

It might first be useful to explore approaches to teaching and learning that will be unlikely to support transformation, before considering teaching and learning approaches that can be a catalyst for transformation. A useful point of departure may be the proposition offered by Freire (2010) that a 'banking' system of teaching and learning will unlikely support transformative learning experiences. Similarly, instrumental learning geared almost exclusively to preparation for the workplace is also unlikely to facilitate transformation (Hultberg and Plos, 2008; Bathmaker and Thomas, 2009). Transformation occurs when learning encourages a deep questioning of "longestablished frames of reference" and the creation of "new meaning schemes" (Mezirow, 1990, p. 5).

However, some commentators argue that HE in FE lacks quality (cf. Feather, 2010; Coffield and Williamson, 2012); that in HE in FE the surface of learning is skimmed and students are never allowed to "go deep enough" (Feather, 2010, p. 195). Learning tasks, including reading, writing, and participating in critical dialogue, can be considered anathema by many HE in FE students, making instances of transformation unlikely (Robbins, 1993, p. 159; cf. Arum and Roksa, 2011). We will now consider the 
context from where the transformation stories emerge, particularly how teaching and learning occurs in a way that we consider might increase instances of transformation.

The teacher should first consider the teaching and learning culture she works in. Does the culture reflect a banking model? If it does, a change in approaches to teaching and learning is necessary. For example, Kegan (2009) makes a distinction between "Informative learning", which he analogises to little more than "form-filling" and "transformative learning" which has the possibility to manifest as noticeable change in the student. We acknowledge that Inform-ative teaching and learning is valuable for the workplace; it gives students the requisite skills to be useful contributors to the economy. However, teachers seeking to facilitate transform-ative learning must be prepared to challenge students at a deeper level (Kegan, 2009, p. 42).

In the context of the BA programme, we have consistently observed that collaborative group learning is a particularly useful teaching and learning approach that encourages students to engage fully with learning. Our observations concur with research that concludes that with collaborative group learning, students can achieve with the help of others what they could not achieve on their own (Sharan, 1990; Shahar and Sharan, 1994); that learning was much more "enjoyable, stimulating and challenging" in small collaborative groups than it was learning in isolation (Costa and O'Leary, 1992, p. 65). Research by Presselen (1992) found that collaborative group learning increases metacognition. Costa and O'Leary (1992) concluded that increased meta-cognition improved academic performance.

A synopsis of collaborative group learning concludes that: groups are more effective than individuals in bringing about change; individual change is facilitated by the support 
of the group; feedback works more effectively in collaborative groups; learning is deeper when the group share perspectives and experiences; learners respond to learning more favourably when there is a positive group culture; learning in a group leads to feelings of social identity and belonging (Askew and Carnell, 1998, pp. 39, 40). Equally as important as the teaching methodologies we use, the establishment of "meaningful, genuine relationships" with students is of particular import in determining students' commitment to learning (Cranton, 2006, p. 5; cf. Rogers, 1983; Daloz, 1999; Arum and Roksa, 2011). Having an empathic understanding of the needs and aspirations of students, of truly "viewing the world" from the students' points of view, can have a significant impact on the learning experience of students (Rogers, 1990, p. 31). Consequently, we seek to encourage open, democratic and meaningful communication that represents a "concentrated" and unprejudiced discourse, the result of which is that the student "acquire[s] a better, more valid, and appropriate understanding of one's insights, attitudes and perceptions" (Illeris, 2014, p.7). To develop "fully-functioning and self-actualised human being[s]" (Daley, 2003, p. 24), the limits of the student's understanding must be first exposed, then challenged, and finally, equipped with new understanding (Illeris, 2014).

\section{The Research Context}

The study from where our transformation stories emerge was undertaken with graduates of a full-time academic Bachelor of Arts (BA) programme, facilitated in a Scottish Further and Higher Education College. Around half of BA participants are mature (25 years+) with caring or work responsibilities, often both. The findings of the 
research indicate that all the participants, to varying degrees, experienced some significant shift in attributes such as confidence, independence and willingness to try new things. We have drawn the transformation stories from a small selection of indepth interviews with participants who self-report shifting from a low to a high selfconcept and where it was concluded, from their point of view, that their experiences of transformation had been significant.

\section{Transformation stories}

The first participant featured is Janice ${ }^{1}$. Prior to returning to education, Janice had experienced some "really serious difficulties coping with life generally",

I had been diagnosed Bipolar by my doctor and it petrified me ... I wasn't coping with everything that was going on around me in my life at that time ... I started having panic attacks and struggled to be with people ... I was more of a recluse back at the house and I was scared to go out after that.

Her husband had previously returned to education. Janice had observed how participating in education had "helped him become more confident and motivated". Janice felt participation might also help her. She had a very difficult start, reporting that,

The first day I nearly walked out of the class ... I thought, "how am I going to do this?' ... I was petrified, I wasn't sure if I was going to be capable of sitting in the classroom for a whole lesson. I wasn't sure if I was going to be able to manage that.

\footnotetext{
${ }^{1}$ Names have been changed
} 
Janice persevered and successfully gained her BA degree. She attributes her successes to the support she received from teaching staff,

It was made clear from the first week that lecturers wanted us to do the best we could do, and they were always available if we needed any help ... they were always there for us.

On what basis can it be argued that Janice has been transformed? Of particular import, the discarding of a social phobia was a significant change. From being, "extremely uncomfortable in company" as a consequence of having had "no self-confidence whatsoever", Janice reports that, "For the first time in many years I have went out for a meal, sat in a pub, went to shows and held interesting conversations". This represents a significant step forward for Janice, attributed to a change of her structure of feeling, whereby she,

... rarely [now] feel[s] stupid talking to others... I have started to believe I have a lot to contribute. I think I can do anything that I set my mind to, and I feel strong for the first time in a very long time.

The second transformation story concerns Elaine. Prior to returning to HE in FE, Elaine felt she was a,

... nobody ... just somebody's mum, just somebody's wife. I always thought 'is this how it is meant to be?'

She reported that "being a mum can really limit you ... certainly my perspective was quite narrow before because my experiences were quite narrow". Elaine found it difficult to juggle the competing commitments of caring for her family and studying, "it 
was a bit of an ordeal trying to juggle everything to make sure you were up to date with college work and that the bairns had everything they needed". Like Janice, with the support of teaching staff who she said "were always around to help in a crisis", Elaine graduated with her BA degree. She reports that,

Learning really open[ed] up how I thought about things ... [I now have] a much wider perspective, ... I now see things in a much wider way ... the world has opened up a lot for me ... it's made me feel more like, I don't know (pause) ... that I have got something to give to society, if you like... I feel like I really have something to contribute now that I didn't before.

Elaine's transformation can be attributed to how she perceives her self-concept. From questioning if being a mother and caring for her children was her only role in life, her perspective has "widened" and she now realises she has more to contribute. June had a similar experience. Caring for a daughter with a,

life-limiting condition ... it was a bit of an ordeal trying to juggle everything to make sure you were up to date with college work and that the bairns had everything they needed.

Her friend was a teacher and June indicates being a "bit in awe" of her friend's education. However she now reports that her own education has made her more, "socially aware in many ways". June reports enjoying speaking about issues she would have little confidence speaking about previously - "[I] want to speak about this kind of stuff now [social issues] and share my opinions with others and hear what they think". June now enjoys, "political conversations" with her teacher friend and feels she has found a new confidence, reporting that, 
I think differently now ... I think more politically than I did before, much more. I had so much to be getting on with in my own life I didn't really consider much else ... I'm a lot more confident as a person because I've done it. You know, I've got a degree and my best pal is a teacher - I always admired her, eh? That she was clever. But I've got a degree the same as her, so I must be clever as well ...

June has experienced a transformation to the extent that she no longer feels inadequate in comparison to others (her friend). She now has confidence because her own education has taken away the feelings of inadequacy. We would argue that this represents a real shift in self-concept. Our final transformation story features Shelley. Before returning to education Shelley was fully occupied in her role as housewife and mother to three young children. She also reports living in financially difficult circumstances. Her self-concept was of,

$[T]$ he wee woman stands at the sink doing the dishes or standing at the cooker or doing something like that ... [a] downtrodden mother of three bairns ... [who]never really knew she was living in poverty ... [I] just thought this is how life is.

Shelley said that it was hard juggling education with looking after the family and had it not been for support from teaching staff and the opportunity to work collaboratively with others, "I would never have been able to do it". Since achieving her BA, Shelley has being doing community work. From seeing herself as the "downtrodden mother of three bairns", she now perceives herself as "very able ... I have grown into a very confident woman". Never having previously taken an interest in politics, she now has a significant leadership, and support, role in her local community. After joining her local 
Tenants Association, she was soon voted as Chairperson. She has since travelled the country speaking at political meetings, highlighting issues face by disadvantaged communities. A highlight was being asked to speak at the Scottish Parliament, "something I thought that I would just never do". Reflecting on how far she has come, Shelley said,

... if somebody had said to me 'would you do that like ten years ago?'. I would have said 'don't be silly', speaking in front of 250 people ... politicians, academics? ... 'you are living on a different planet' ... now, I think it's in my blood, I enjoy it.

As for an indicator of her transformation; when asked how she now feels about herself, Shelley's response was, "Well it feels - I'm very powerful ... people respect me more".

\section{Conclusions}

Our key proposition was that, despite being subjected to some sustained but in many ways valid criticism, transformative learning theory continues to be useful to educators as an organising concept. We presented our position by first reviewing the literature, clarifying what transformation means, in the context of teaching and learning, and from where transformative learning theory emerged; principally from the early research by Jack Mezirow. We also made the point that approaches to teaching and learning, the teaching and learning environment, and the relationships teachers develop with students, all have an important role in encouraging transformation. We reported how transformation is realised in the context of the BA programme, there will be other, 
equally effective approaches we are sure. Nonetheless, if it is true that nurturing transformation must be an explicit goal of teaching and learning; then teachers ought to explore teaching and learning approaches that are likely to increase instances of transformation. It was important that examples of students' experiences of transformation were reported. Space only allowed us to report four transformation stories. This is regrettable as the findings of the research indicated that all the research participants, to varying degrees, experienced some significant shift in attributes such as confidence, independence and willingness to try new things, the confluence of which represented real shifts in self-identity (Illeris, 2014). How participants reported experiencing, conceptualising and participating in their social worlds has become more discriminating. It may well be that experiences of transformation becomes a way of defining excellence. We guess that these kinds of experiences are common across the $\mathrm{HE}$ in FE 'sector'.

Transformative learning theory will continue to receive adverse criticism until a way is developed to objectively measure transformation; making a transformation inventory a pressing need (see King, 2004). Also, more longitudinal studies, or other follow-up mechanisms, could confirm that transformation is persistent. Finally, more rigorous methods of triangulation may also address concerns about internal and external validity (Snyder, 2008, p. 176). We acknowledge these criticisms but suggest that it is within the bounds of possibility that the way we teach can change lives. Also, in the changing of lives for the better we might still find transformative teaching and learning a useful organising concept. 


\section{References}

Arum, R. and Roksa, J. (2011) Academically Adrift: Limited Learning on College Campuses. Chicago II: University of Chicago Press.

Askew, S. and Carnell, E. (1998) Transforming Learning: Individual and Global Change. London: Cassell.

Bathmaker, AM. and Thomas, W. (2009) Positioning themselves: an exploration of the nature and meaning of transitions in the context of dual sector FE/HE institutions in England. Journal of Further and Higher Education. 33(2). 119-130.

Bitterman, J. (2015) Mezirow's legacy: the evolution and impact of transformative learning. Panel contribution delivered to the Academic Festival 2015.Teachers College; Columbia University, New York

https://www.bing.com/videos/search?q=youtube+transformative+learning\&view=detai I\&mid=73F0B1E6981F87FD101F73F0B1E6981F87FD101F\&FORM=VIRE (retrieved $26^{\text {th }}$ October 2017).

Brookfield, S.D. (2015) The Skillful Teacher; On Technique, Trust and Responsiveness in the Classroom $3^{\text {rd }}$ Edition. San Francisco CA: Jossey-Bass.

Burke, P.J. (2012) The Right to Higher Education: Beyond Widening Participation. London: Routledge.

Coffield, F. (2008) Just Suppose Teaching and Learning Became the First Priority .... London: Learning and Skills Network.

Coffield, F. and Williamson, B. (2012) From Exam Factories to Communities of Discovery. London: University of London.

Cooper, A. (2013) Why we need to protect the university. The Guardian. April 3. http://www.guardian.co.uk/higher-education-network/blog/2013/apr/03/universitytitle-protection-regents-college (retrieved April 15th 2013).

Costa, A.L., and O'Leary, P.W. (1992) Co-cognition and co-operative development of the intellect. In Davidson. N., and Worsham, T. (Ed's.) Enhancing Thinking Through Cooperative Learning. London: Teachers College Press.

Cranton, P. (1996) Types of group learning. New Directions for Adult and Community Education. 71. 25-32.

Cranton, P. (2006) Understanding and Promoting Transformative Learning; A Guide for Adult Educators $2^{\text {nd }}$ Edition. San Francisco: Jossey-Bass.

Creasy, R. (2013) HE-lite: exploring the problematic position of HE in FECs. Journal of Further and Higher Education. 37(1). 38-53. 
Cross, P. K. Foreward to Daloz, L.A. (1999) Mentor: Guiding the Journey of Adult Learners. San Francisco CA: Jossey-Bass.

Daley, B.J. (2003) A case for learner-centred teaching and learning. New Directions for Adult and Continuing Education. 98. 23-30.

Daloz, L.A. (1986) Effective Teaching and Mentoring. San Francisco CA: Jossey-Bass.

Daloz, L.A. (1990) Pointing the way through the fire: mentorship, transformation and institution. Religion and Intellectual Life. 6(2). 73-85.

Daloz, L.A. (1999) Mentor: Guiding the Journey of Adult Learners. San Francisco CA: Jossey-Bass.

Dirkx, J.M. (1998) Transformative learning theory in the practice of adult education: an overview. Journal of lifelong Learning. 7. 1-14.

Dirkx, J.M. (2000) After the burning bush: transformative learning as imaginative engagement with everyday experiences. In Wiessner CA, Meyer S and Fuller D (Ed's) Challenges of Practice: Transformative Learning in Action. New York: Teachers College, Columbia University.

Egan, S.J. (1985) Learning Process in Family Therapy: An Experiential perspective. Unpublished doctoral dissertation. Toronto: University of Toronto.

Feather, D. (2010) A whisper of academic identity: an HE in FE perspective. Research in Post-Compulsory Education. 15(2). 189-204.

Freire, P. (2010) Banking versus problem-solving models of education. In Curren R (Ed.) Philosophy of Education: An Anthology. Oxford: Blackwell Publishing.

Griffith, C. and Golding Lloyd, M.G. (2009) Degree of success? A review of delivering BSc honours degrees in an FE college. Journal of Further and Higher Education. 33(4). 483-492.

Habermas, J. (1984) The Theory of Communicative Action Volume 1: Reason and Rationalisation of Society. Cambridge: Cambridge University Press.

Hawkins, P. and Mills, D. (2010) Home or away? Widening participation and the challenge for anthropology. Anthropology in Action. 17(2/3). 8-19.

Hoggan, C.D. (2015) Transformative learning as a meta-theory: definition, criteria and typology. Adult Education Quarterly. 66(1). 57-75. 
Hultberg, J. Plos, K. Hendry GD and Kjellgren KI (2008) Scaffolding students' transition to higher education: parallel introductory courses for students and teachers. Journal of Further and Higher Education. 32(1). 47-57.

Illeris, K. (2014) Transformative Learning and Identity. New York NY: Routledge.

Kegan, R. (2009) What "form" transforms? a constructive-developmental approach to transformative learning. In Illeris K (Ed.) Contemporary Theories of Learning: Learning Theorists ... in Their Own Words. London: Routledge.

King, P.K. (1997) Examining Activities that Promote Perspective Tansformation among Adult Learners in Higher Education. Unpublished doctoral dissertation. Philadelphia. Widner University.

King, P. (2004) Both sides now: examining transformative learning and professional development of educators. Innovative Higher Education. 29(2). 155-174.

Lavender, P. Derrick, J. and Brooks, B. (2004) Testing, testing...1, 2, 3': assessment in adult literacy, language and numeracy. Leicester: NIACE.

Lawson, A. (2014) Learner identities in the context of undergraduates: a case study. Educational Research. 56(3). 343-356.

Leach, L. (2011) 'I treat all students as equal': further and higher education teachers' responses to diversity. Journal of Further and Higher Education. 35(2). 247-263.

Learning and Work Institute (2017) Quality assuring non-regulated provision: the expanding role or RARPA Leicester: L\&WI.

Maslow, A.H. (1943) A theory of human motivation. Psychological Review. 50. 370-396.

McArthur, J. (2011) Reconsidering the social and economic purpose of higher education. Higher Education Research and Development. 30(6). 737-749.

Merriam, S.B. and Bierema, L.L. (2013) Adult Learning: Linking Theory and Practice. San Francisco CA:Jossey-Bass.

Merriam, S.B. and Kim, S. (2012) Studying transformative learning: what methodology. In Taylor, E.W. and Cranton, P. (Ed's) The Handbook of Transformative Learning: Theory, Research and Practice. San Francisco CA: Jossey-Bass.

Mezirow, J. (1975) Education for Perspective Transformation: Women's Reentry Programmes in Community Colleges. New York: Center for Adult Education, Teachers College. Columbia University.

Mezirow, J. (1978a) Perspective Transformation. Adult Education. 100-110.

Mezirow, J. (1978b) Education for Perspective Transformation: Woman Re-entry Programs in Community College. New York; Center for Adult Education. 
Mezirow, J. (1981) A Critical Theory of Adult Learning and Education. Adult Education. 32. 3-23.

Mezirow, J. (1990) How critical reflection triggers transformative learning. In Mezirow J and Associates (Ed's.) Fostering Critical Reflection in Adulthood: A Guide to Transformative and Emancipatory Learning. San Francisco CA:Jossey-Bass.

Mezirow, J. (2000) Learning to think like an adult: core conceptions of transformative theory. In Mezirow, J. and Associates (Ed's.) (2000) Learning as Transformation: Critical Perspectives on a Theory in Progress: San Francisco CA: Jossey-Bass.

Newman, M. (2012) Calling transformative learning into question; some mutinous thoughts. Adult Education Quarterly. 62(1). 36-55.

Parker, J. (2003) Reconceptualising the curriculum: from commodification to transformation. Teaching in Higher Education. 8(4). 529-543.

Pascall, G. and Cox, R. (1993) Women Returning to Higher Education. Buckinghamshire: Open University Press.

Philipi, J. (2010) Transformative learning in healthcare. Journal of lifelong Learning. 19. 39-54.

Presselen, B.Z. (1992) A perspective on the evolution of co-operative thinking. In Davidson, N., and Worsham, T. (Ed's.) Enhancing Thinking Through Co-operative Learning. London: Teachers College Press.

Robbins, D. (1993) The practical importance of Bourdieu's analyses of higher education. Studies in Higher Education. 18(2). 151-63.

Rogers, C.T. (1983) Freedom to Learn for the 80's. London: Merrill.

Rogers, C.T. (2004) On Becoming a Person: A Therapists View of Psychotherapy. London: Constable and Robinson Ltd.

Sen, A. (2006) Identity and violence: the illusion of destiny New York: WW Norton.

Shahar, H., and Sharan, S. (1994) Talking, relating and achieving: effects of cooperative learning and whole-class instruction. Cognition and Instruction. 12(4). 313-353.

Sharan, S. (Ed.) (1990) Cooperative Learning: Theory and Research. New York: Praeger.

Snyder, C. (2008) Grabbing hold of a moving target: identifying and measuring the transformative learning process. Journal of Transformative Education. 6(3). 159-181.

Taylor, E.W. (2000) Analysing research on transformative learning theory. In Mezirow and Associates (Ed's.) Learning as Transformation: Critical Perspectives of a Theory in Progress. San Francisco: Jossey-Bass. 
Taylor, E.W. and Cranton, P. (Ed's) (2012) The Handbook of Transformative Learning: Theory, Research, and Practice. San Francisco: Jossey -Bass.

Tisdell, E.J. (2012) Themes and variations of transformational learning: interdisciplinary perspectives on forms that transform. In Taylor, E.W. and Cranton, P. (Ed's) The Handbook of Transformative Learning: Theory, Research and Practice. San Francisco CA: Jossey-Bass.

Walton, J. (2014) What can the 'transpersonal' contribute to transformative research? International Journal for Transformative Research. 1(1). 25-44.

Watkins, K.E. Marsick, V.J. and Faller, P.G. (2012) Transformative learning in the workplace: leading learning for self and organisational change. In Taylor, EW and Cranton, P (Ed's) The Handbook of Transformative Learning: Theory, Research, and Practice. San Francisco: Jossey -Bass. 